Marta Frątczak-Dąbrowska, Joanna Jarząb-NapieraŁa

Uniwersytet im. Adama Mickiewicza w Poznaniu

\title{
The Crisis of Brexit and Other Socio-Cultural Aspects of Silencing the Past through the Example of Anna Burns' Milkman
}

Where to be saved you only must save face and whatever you say, you say nothing

Seamus Heaney, North (59)

In Postcolonial Melancholia (2004), Paul Gilroy investigates a systemic whitewashing of history, which, according to him, has been taking place in the UK in recent decades. The revisionist accounts of British history "salve the national conscience, but ... [also] command the marginality of colonial history," "feed[ing] the illusion that Britain has been or can be disconnected from its imperial past" (2). In Gilroy's eyes, this postcolonial melancholia stems from a collective "inability even to face, never mind actually mourn ... the end of the empire" (90). It goes hand in hand with the glorification of a "pure" national identity and the Second World War as the last, bright example of British might. For Gilroy, this cultural phenomenon is an expression of a deeply rooted longing for a "long lost homogeneity" of the nation from before the invasion of the "aliens" from postcolonial and post-communist countries; unless openly confronted, he adds, it will only deepen the general atmosphere of distrust towards the Other and facilitate hostile attitudes towards the newcomers (89). In 2016, twelve years after the publication of the book, Gilroy's words proved prophetic as the greatest political crisis in British post-war history-Brexit-began to undermine the integrity of the UK; in Brexit debates, little thought was given to the inherent diversity of the UK, with Scottish and Northern Irish voices being downplayed in favour of the English. The dominant narrative was that of a glorification of the imperial past, nationalist, anti-immigrant or even war-like rhetoric; Boris 
Johnson was urged to seize his "Churchill moment" in taking a hard stance with the EU (Cooper 2020) and Arlene Foster, the leader of the Democratic Unionist Party, used Churchill's quotes to evoke the sense of solidarity among her Northern Irish voters (Moriarty 2020). Needless to say, such discursive practices proved very effective as they struck a familiar chord with the Brexit supporters' sense of a post-imperial nostalgia (Gilroy 90); for them, Brexit was a symbolic opportunity to revisit the past in all its imagined glory.

In this political paradigm, Northern Ireland occupies an uneasy space. Closer to home than other former colonies, it is a reminder of the catastrophic consequences of the British colonial rule. The cruelty of the imperial administration is not a welcomed subject of political debates, especially in conservative circles; the realities of the imperial past, however, "can only be denied at a considerable moral and psychological cost" (Gilroy 94) for the victims and the oppressors alike. This "hidden, shameful store of imperial horrors has been an unacknowledged presence in British political and cultural life during the second half of the twentieth century" (Gilroy 94), and Northern Ireland is the very embodiment of the messy and cruel nature of British imperial politics. As such, it is viewed by many on the Conservative side as an obstacle to fulfilling their vision of Brexit. Constant struggles over the legacy of the Troubles and the shape of the Irish border, with the EU defending the island's integrity, were either brushed off as scaremongering or openly ignored by the Tory party. Let us take into account Karen Bradley, Northern Irish Secretary in Theresa May's government, who openly admitted to having no knowledge of Northern Irish history (Carroll 2018), or Boris Johnson comparing the Irish border to the "borders" between London councils (Watts 2018). This is why the present article views the silence which surrounded the issue of the Irish Border and Northern Ireland in Brexit debates as symptomatic and connected with the broader phenomenon of institutionalised forgetting about the past. We approach Brexit as a post-imperial conflict within which Northern Ireland has been side-lined from mainstream debates in the UK. In other words, it became an ideological and political victim of the Brexit project; one may repeat after The Guardian that the Northern Irish were "the invisible people of the Brexit crisis"; as one of interviewees says: “[i]t's Northern Ireland. Nobody wants us anyway, not in London or Dublin. We're just the scapegoat” (O'Carroll 2019).

Thus, awarding the Man Booker Prize for Fiction (2018) to Anna Burns for a novel about the Troubles now seems like a missed opportunity to change the narrative. It was the first time in history that a Northern Irish writer had won the prize and a tremendous success for Anna Burns, who pushed Northern Irish literature beyond its local readership. The success of the novel coincided with 
the Brexit crisis caused by the DUP's refusal to accept the so-called backstop. ${ }^{1}$ At that very moment, Milkman could have been read as a commentary on the consequences of reinstituting the Irish border, its meaning during the Troubles and, later, its disappearance as a key point in the peace-process negotiations. The choice of this particular text for such a prestigious award could also have been interpreted as a reaction of the British literary scene to the fiasco of the Brexit negotiations and a criticism of the negligent behaviour of British politicians towards the Irish border issue. However, the justification of the award published on the Man Booker Prize's site moves the reader's attention away from the local context of the novel; it argues that the text's universal message is more significant than its local setting. ${ }^{2}$ This seemingly innocent act of diminishing the novel as being first and foremost an intimate account of the 1970's Troubles in Belfast is symptomatic and in line with Gilroy's observations. Interestingly enough, Orwell's Prize for Political Fiction, awarded to Milkman the following year (2019), is an intriguing response to the elusive justification of the Booker Prize; according to the Orwell Prize judges, the text reflects "a specific time and a specific conflict" (Sutcliffe 2019) and places the Northern Irish experience of sectarian violence and post-imperial politics at the very centre of the debate.

\section{Northern Irish Postcolonial Amnesia}

While such struggles on the British side may not come as a surprise to those who followed the Brexit arguments closely, the situation of Milkman on its local market is not so well known. In 2018, Leszek Drong described his journey to Ardoyne, Belfast, a month after Milkman won the prize. In the article, Drong depicts the novel's reception, or more precisely the lack of it, by the local community. Anna Burns, brought up in this republican district of Northern Ireland's capital, in which she also placed the action of her novel, was literally unknown at home, and the local library did not have Milkman on its shelves

1 The Irish backstop was a protocol in the withdrawal agreement introduced by Theresa May whereby Northern Ireland was to remain within the Single Market so as to avoid the reinstatement of the hard border. The idea was supported by the Irish government and the EU, but strongly opposed by the DUP and Boris Johnson's new administration. It was ultimately scraped for the border on the Irish Sea.

2 The justification of the Booker Prize 2018 reads: "Burns draws on the experience of Northern Ireland during the Troubles ... [y] et it is never a novel about just one place or time. The local is in service to an exploration of the universal experience of societies in crisis" (The Booker Prize 2018). 
(Drong 2018). These examples well illustrate how this particular novel appears to have become a victim of the peoples' willingness that is present on both the British and Northern Irish sides to forget about the past. In Drong's words, "Brexit is a massive failure of memory," whilst Milkman is one of those novels which aim at "highlight[ing] lapses in collective remembrance" (Drong 2020: 171-80). We would like to push the argument further by stating that Brexit dislodges the ongoing process of silencing the memory about the Troubles. On the British side, it has taken the form of postcolonial melancholia, whereas on the Northern Irish side, the form of postcolonial amnesia. "Postcolonial amnesia" is here understood as a phenomenon associated with new (nation) states that emerge after colonization and display "the urge for historical self-invention or the need to make a new start" (Gandhi 4). The urge "to erase painful memories of colonial subordination" leads to a systematic forgetting about the past of subordination and trauma (Gandhi 4 ). In the long run, however, as Paul Gilroy noted, the effects of such a process are only negative; they prevent the communities involved from facing their past as well as from moving forward (3).

Patrick Radden Keefe in his non-fiction text concerning the problem of murder and memory during the Troubles, tellingly entitled Say Nothing, discusses the local community's strategy of keeping silent as an ageless form of loyalty to republicans and resistance to the British; as Keefe writes, there was a “'wall of silence' [which] protected the IRA. Informers were known as 'touts', and for centuries they have been reviled in Irish culture as the basest species of traitor" (80). Although many Northern Irish writers widely responded to the tragic events taking place during the three decades of the conflict-Bernard MacLaverty, Deirdre Madden, or Glenn Patterson-the majority of the Northern Irish society preferred to remain silent even after the symbolic Good Friday/ Belfast Agreement in 1998. The Northern Irish community tired of the conflict appeared to have welcomed Belfast's city council's idea of promoting the capital as a cosmopolitan European city. Consequently, non-denominational districts occupied by immigrants began to appear on the map of the city, especially in the Queen's University area. Such investments as the Titanic Museum or the film studio, where many scenes of the Game of Thrones were shot, resulted in the creation of a new image of the city - the "export" Belfast as Aleksandra Łojek calls it (11). For Łojek, however, the money invested in museums, cultural events, concerts, and flourishing tourism is a facade intended to hide the unwanted truth about the sectarian part of Belfast, namely the one which has not come to terms with the violent past. Thus, Łojek concludes, the Belfast upper and middle class, which gained most from the symbolic departure from sectarianism, turns a blind eye to the underprivileged and denies the link between the city's 
past and its present-day reality (12). The phenomenon of social amnesia has also been acutely observed by Glenn Patterson, a Northern Irish writer, who grew up in the Troubles-era Belfast. In his article "Belfast, a Brick and the G8 Summit," 3 the novelist draws attention to the fact that in 2013 a brick in his hand, which in the times of the Troubles was used as a weapon in the street fights, no longer evoked any associations among police officers; twenty years ago, it would have been unbelievable (Patterson 2013). It transpires that, at least for a brief moment, Belfast citizens had succeeded in forgetting about the conflict, since one of its core symbols had lost its meaning. Such attempts at silencing the past are a motif that runs through Burns' novel as well.

\section{Milkman: Reading/Writing-while-forgetting}

The narrator-protagonist of the novel is a young woman whose attitude to the Northern Irish reality of the second half of the twentieth century may be best characterised by the word "escapism." One of the physical manifestations of her approach is her peculiar practice of "reading-while-walking," characterised in the novel as an "unsafe procedure" and "[the process of] cutting off consciousness and not paying attention and ignoring your surroundings" (Burns 58). While walking the streets of Belfast, she holds an open book in front of her, much like today's teenagers stubbornly looking at the screens of their phones. Her behaviour is viewed by other members of the community as peculiar and hostile. In a world permeated by vigilance and mutual distrust, where any passer-by may be an enemy, she conspicuously displays her lack of engagement with reality. Her choice of reading material is notable as well. Namely, she reads novels from the eighteenth and nineteenth centuries, as more contemporary texts are, in her opinion, too closely connected with the twentieth century:

Every weekday, rain or shine, gunplay or bombs, stand-off or riots, I preferred to walk home reading my latest book. This would be a nineteenth-century book because I did not like twentieth-century books because I did not like the twentieth century. (5)

"[N]ineteenth-century [provided] safe-and-sound literary thoughts" (115), she adds. Like for many Brexiteers, an imagined, pre-war past becomes her refuge. The time of omniscient narrators; social realism and progress built safe

3 The title openly refers to Ciaran Carson's poem "Brick" from 1989, which names bricks thrown by the local community in the Troubles riots as "Belfast Confetti" (Carson 72). 
frames, which hid the chaotic nature of the world that exploded in the twentieth century. She, thus, tries to ignore the sectarian divisions which structure her world-religious, political, sexual, symbolic-denying, to the astonishment of her friends and family, any opportunity to learn more about the politics of the day: "Knowledge didn't guarantee power, safety or relief and often for some it meant the opposite of power, safety and relief .... Purposely not wanting to know therefore, was exactly what my reading-while-walking was about" (65).

Silence, then, has a material presence in the text and the unnamed protagonist's struggles not to face reality are a testimony of the Northern Irish communal experience. Like in Say Nothing, keeping silent is at times synonymous with safety: "rarely did I mention anything to anybody. Not mentioning was my way to keep safe" (44), while at other times it is a defence mechanism: "So 'I don't know' was my three-syllable defence in response to the questions" (174). Also, a strategy of not-naming things, objects, people or phenomena builds a barrier between the citizens and reality, since problems not named do not truly exist. Her older sister, then, who lives in England, becomes "the unmentionable second sister" (45); England is the land over the sea, where we meet "Somebody McSomebody," and so on. Though such a narrative choice naturally brings to the critic's mind the allegorical dimension of the text, it is vital to note that in Milkman it stems first and foremost from the tangible experience of Northern Irish communities and their strategies of survival rather than from the author's primary pursuit to give her novel a universalist message. As the friend of the protagonist says,

Your memory! All those mental separations and splittings-off from consciousness ... The things you notice yet not notice, friend. The disconnect you have going between your brain and what's out there. This mental misfiring-it's not normal. It's abnormal-the recognising, the not recognising, the remembering, the not remembering, the refusing to admit to the obvious. (207)

Despite the negative comments from friends and relatives, the protagonist purposefully insists on keeping the amnesiac status quo in the middle of the sectarian conflict. Elsewhere, we see her actively supressing her memory of political violence, and avoiding possible confrontation with the real world: "Well, I was going to have amnesia of course. In fact, here I was, already having it. 'I don't know what you mean,' I said. 'I've forgotten'" (66). Hence, this peculiar Northern Irish cultural amnesia has its onset in the time of the Troubles; whilst it appears to have further developed during the post-Troubles times when 
economic prosperity, known under the name of the Celtic Tiger, made it easy to forget about past violence and focus on the supposedly prosperous future. As the already quoted reportage by Łojek and essay by Patterson argued, for the last three decades Belfast has tried to assume a new, cosmopolitan identity, so different from its sectarian past that it has become barely recognisable. In the short term, it has proved effective, ensuing a protective web of silence over wounded communities, but in the long run it has prevented the Northern Irish from facing their past and its consequences. The narrator of the novel is well aware of this paradox:

It was the convention not to admit it, not to accept detail, for this type of detail would mean choice and choice would mean responsibility and what if we failed in our responsibility? Failed too, in the interrogation of the consequence of seeing more than we could cope with? (70-71)

From a temporal and spatial distance, the narrator seems to be able to see through the strategies once employed by her community in order to survive, the most vital of which was that of actively forgetting the past. However, with hindsight, it transpires that such a choice of a strategy proved to be counterproductive. Neither has the society gone through the painful process of reconciliation with the past, nor have the British acknowledged their negative role in the conflict. Hence, the ghosts of the past keep haunting the present in various forms, the most recent example of which is the series of riots in Belfast in April 2021 accompanied by Boris Johnson expressing his deep concern over the resurgence of violence-the possibility of which many have warned him about earlier on (Leebody, Bell 2021).

Hence a similar cultural process has taken place on both sides of the border, albeit for different reasons. England aimed to forget the imperial aspect of the Northern Irish history, while for Northern Irish silencing the past was a strategy of survival and then an attempt to rebuild their shattered, communal identity as if above and beyond their old sectarian divisions. For the Brexiteers, in turn, it became a political project rooted in the revisionist historical accounts and media discourse committed to spreading historical ignorance which, in time, changed into a tangible force embodied by Brexit. The comments during the Brexit campaign, as well as expert analyses after the referendum, in many respects provide a similar diagnosis. As Fintan O'Toole (2016) observes, "England has not had the time, nor made the effort, to develop an inclusive, civic, progressive nationalism. It is left with a nationalism that is scarcely articulated in positive terms at all and that thus plugs into the darker energies of resentment 
and xenophobia." The crisis of British identity, having its onset in the collapse of the British Empire, has further deteriorated since the UK's accession to the European family. As the Remain did not succeed in conveying a convincingly positive vision of British identity within the EU, the old colonial sentiments revived by the Brexiteers have resulted in the majority of the British positively responding to the Brexit slogan of "bringing back control" over their borders, their lands and their lost (colonial) identity. Similarly, post-referendum statements such as "Brexit means Brexit," or "No deal is better than a bad deal," are read as desperate cries of the British government to the public, by creating an illusion of the regained decision making position of their country, which intends to go back to the old practice of imposing their will on others; by the same token, it shows that part of British identity is not to negotiate but to rule (Johns 2018). Thus, the negligent treatment of the Irish border in the Brexit campaign and during the negotiations with the European Union appears to have been a strategy of the Conservatives to keep the issue of the Northern Irish problem silenced for as long as possible so as to maintain the illusion of the UK's integrity. At the same time, Northern Irish elites, deeply divided and just as reluctant to look into the past as their British counterparts, did not manage to successfully safeguard their people's interests in the post-Brexit world. Though, as the example of Milkman shows, literature's ability to tangibly influence reality is limited, the intriguing (hi)story of the novel's publication and reception allows one to better understand how the ghosts of the European imperial past continue to live on in the present-day political struggles and to comprehend how they still affect the future of the continent.

\section{| Works Cited}

Burns, Anna. Milkman. London: Faber \& Faber, 2018.

Carroll, Rory. "Karen Bradley Admits Ignorance of Northern Ireland Politics."

The Guardian, 7 Sept. 2018, https://tinyurl.com/yzh6vp4b. Accessed

28 Feb. 2019.

Carson, Ciaran. "Brick." Belfast Confetti. Winston-Salem: Wake Forest University Press, 1989. 72.

Cooper, Charlie. "Boris Johnson faces up to his history moment." Politico, 19 March 2020, https://tinyurl.com/yazmnn9y. Accessed 3 April 2020.

Drong, Leszek. "Remembering a Transcultural Past: Recent Post-Tribal Fictions of Seventies Ardoyne." Critique: Studies in Contemporary Fiction 61.2 (2020): 171-180. 
---. “O mrocznym Mleczarzu w wasserenglish.” (“On Milkman in Wasserenglish”) Wachtyrz.eu, 25 Nov. 2018, https://tinyurl.com/8ntfzp7f. Accessed 28 Feb. 2019.

Gandhi, Leela. Postcolonial Theory: A Critical Introduction. Crows Nest NSW: Allen and Unwin, 1998.

Gilroy, Paul. Postcolonial Melancholia. New York: Columbia University Press, 2005.

Heaney, Seamus. "Whatever You Say Say nothing." North. London: Faber and Faber, 1975. 57-60.

Johns, Chris. "Semantics of Brexit Means Nobody Knows What's Going On”, The Irish Times, 10 Jun. 2018, https://tinyurl.com/4xm9kfue. Accessed 6 April 2021.

Keefe, Patrick Radden. Say Nothing: A True Story of Murder and Memory in Northern Ireland. London: William Collins, 2019.

Leebody, Christopher, and Jonathan Bell. "Both Sides Committed 'Serious Criminal Offences', in Belfast Disorder.” Belfast Telegraph, 8 Apr. 2021, https://tinyurl.com/fz9zrc5m. Accessed 9 April 2021.

Łojek, Aleksandra. Belfast. 99 ścian pokoju. (Belfast. 99 Peace Walls.) Wołowiec: Wydawnictwo Czarne, 2015.

Moriarty, Gerry. "Winston Churchill Name-checked in Belfast as Clock Ticks towards Brexit." The Irish Times, 30 Dec. 2020, https://tinyurl.com/2dyyaesc. Accessed 25 Jan. 2021.

O'Carroll, Lisa. “Nobody wants us"': Fears of Forgotten on Northern Irish Border.” The Guardian, 29 Sept. 2019, https://tinyurl.com/2r6s6a5p. Accessed 1 Oct. 2019.

O'Toole, Fintan. "Brexit Fantasy is About to Come Crashing Down." The Irish Times, 25 Jun. 2016. https://tinyurl.com/pxsrwbzt. Accessed 6 April 2021.

Patterson, Glenn. "Belfast, a Brick and the G8 Summit." The Guardian, 20 Jun 2013. https://tinyurl.com/pkxxhj4. Accessed 1 February 2021.

Sutcliffe, Tom. "Milkman." The Orwell Foundation, https://www.orwellfoundation.com/political-fiction/milkman/. Accessed 13 January 2020.

“The Booker Prize: 2018 Winner Milkman." The Booker Prizes, https://thebookerprizes.com/fiction/backlist/2018. Accessed 30 January 2021.

Watts, Joe. "Brexit: Boris Johnson Says Handling Irish Border Problem like Managing Congestion Charge Boundary between London Councils." The Independent, 27 Feb. 2018, https://tinyurl.com/4yrfspey. Accessed 28 February 2019. 


\section{| Abstract \\ Marta Frątczak-Dąbrowska, Joanna Jarząb-NapieraŁa \\ The Crisis of Brexit and Other Socio-Cultural Aspects of Silencing the Past through the Example of Anna Burns' Milkman}

The present article scrutinizes the phenomenon of a systemic silencing of the past visible in recent socio-political challenges caused by Brexit, especially in the case of the Irish border. Due to the comparative character of the paper, the attention is targeted at a symptomatic amnesia manifested on the British and Northern Irish sides. Postcolonial melancholia, to use Paul Gilroy's term, facilitated by a systemic whitewashing of British imperial past, is contrasted here with Northern Irish postcolonial amnesia understood as a personal and institutionalised suppression of the difficult memory of colonisation and violence. In what follows, the paper aims to show how these two phenomena meet in the conflict of Brexit and how literature comments on the current political, social and cultural issues such as Brexit based on the example of Anna Burns' novel Milkman (2018). The article discusses the silence which has surrounded the issue of the Irish Border in Brexit debates, as well as looks at the Northern Irish reluctance to talk about their past as an unsuccessful attempt to escape the demons of the past.

Keywords: Brexit; Northern Ireland; Anna Burns; Milkman; postcolonial melancholia; postcolonial amnesia

\section{| Abstrakt}

Marta Frątczak-Dąbrowska, Joanna Jarząb-NapieraŁa

Kryzys wywołany brexitem oraz pozostałe aspekty wyciszania przeszłości na przykładzie powieści Milkman Anny Burns

Niniejszy artykuł przygląda się systemowemu uciszaniu przeszłości, które odegrało ważną rolę w dyskursie brexitu, a było szczególnie widoczne w odniesieniu do kwestii granicy irlandzkiej. Artykuł ma charakter porównawczy i skupia się na zjawisku społeczno-kulturowej amnezji widocznej zarówno po brytyjskiej, jak i po północnoirlandzkiej stronie. W artykule używany jest termin postkolonialnej melancholii Paula Gilroya, a opracowanie pokazuje, jak wybielanie brytyjskiej imperialnej historii, które stało się częścią narracji głównego nurtu w dyskursie brexitu, spotyka się z północnoirlandzką postkolonialną amnezją rozumianą jako instytucjonalne 
wyparcie trudnej pamięci o północnoirlandzkim doświadczeniu kolonizacji i przemocy. Artykuł prezentuje, na przykładzie książki Anny Burns pod tytułem Milkman (2018), jak wspomniane wyżej zjawiska odbijają się w literaturze oraz definiują jej społeczno-kulturowe znaczenie. Ilustruje także, w jaki sposób kształtują one odbiór powieści, która dotyka bieżących problemów społeczno-politycznych.

Słowa kluczowe: brexit; Irlandia Północna; Anna Burns; Milkman;

postkolonialna melancholia; postkolonialna amnezja

\section{| About the Authors}

Marta Frątczak-Dąbrowska is an assistant professor at the Faculty of English, Adam Mickiewicz University, Poznań, Poland. She gained her $\mathrm{PhD}$ in postcolonial studies and is currently working on a research project sponsored by the National Science Centre, Poland. Her articles were published in journals such as Commonwealth Essays and Studies, Journal of Postcolonial Writing, Nordic Journal of English Studies, Studia Anglica Posnaniensia. Her latest chapter is part of the collection entitled The Economics of Empire: Genealogies of Capital and the Colonial Encounter (Routledge 2021).

E-mail: mfratczak@amu.edu.pl

ORCID: 0000-0003-4739-5591

Joanna Jarząb-Napierała is an assistant professor at the Faculty of English, Adam Mickiewicz University, Poznań, Poland. She is the author of a monograph Houses, towns, cities - the changing perception of space and place in contemporary Irish novels (2016) and a co-author of a monograph Between the Self and the Other. Essays on the Poetry of Paul Muldoon (2018). Currently she is working on a project "Irish cosmopolitanism - the case of Russian literary and cultural influence on the development of new Irish prose" financed by the National Science Centre, Poland. E-mail: joanna.jarzab@amu.edu.pl

ORCID: 0000-0002-6519-8295 